\title{
ONE-, TWO-DIMENSIONAL MODEL OF PERSONAL IDENTITY AND PERSONAL BEING, AS AN ACCUMULATOR OF "ZOMBIES" ONTOLOGY (REGRESSIVE TENDENCY OF COMBINING A LIVING BODY AND A CORPSE WITHIN A SEMANTIC FIELD OF THE "BODY" CONCEPT IN 19 EUROPEAN LANGUAGES AND IN ALL HIEROGLYPHIC LANGUAGES
}

\author{
Nikita Nikolov \\ State Budgetary Educational Institution of Continuing Professional Education Chelyabinsk \\ Institute of Personnel Development and Continuing Education \\ 88 Krasnoarmeyskaya str., Chelyabinsk, Russian Federation, 454091 \\ nikitanikolov89@gmail.com
}

\begin{abstract}
The aim of research is revealing the correlation of one-, two-dimensional models of personal identity and the ontology of a dead body without signs of consciousness ("zombies"). Research methods are hermeneutic and systemic structural. The author pays special attention to the phenomena of "philosophical, social, soulless zombies". It is specified that such concepts as anima (Latin), fren (Greek), 灵魂 (Chinese), 精神 (Chinese), आत्मन (atman) (Sanskrit), बुद्धि (Buddhi) (Sanskrit), jُ (ruh) (Arabic),

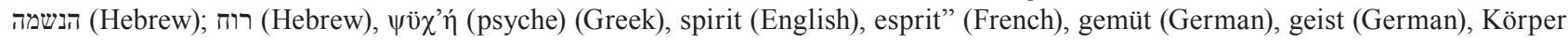
(German),body (English), corpus (Latin), Le corps (French), chair (French) contribute most to the deformation of personal identity. Both the transcendental form of identity (spirit, soul) and material (human body) are subject to deformation. Using the example of the substitution of the "god of the morning" (Lucifer) for the "devil" (Satan) within the Latin language, the practice of influencing the collective consciousness of people of the transformational power of letters-symbols relating to the structure of the alphabetical plan of two-dimensional dimension (as understood by A. Sviridov). It is revealed that the concepts of transformation of personal identity within 19 European languages and all hieroglyphic languages are created today by critical masses of people whose consciousness is congruent with the phenomenon of "social zombie".
\end{abstract}

Keywords: personal identity, spirit, soul, body, philosophical, social, soulless zombie.

\section{Introduction}

Issues of personal identity today are considered by various humanities. At the same time, in our opinion, the structural anthropology approaches that take into account the structural linguistic methodology are the most effective. One of the interesting theories in this regard is the theory of the alphabetical plans of the languages of the world. Its methodology, taking into account the approaches of the philosophy of language, theories of linguistic determinism, approaches of analytical psychology, as well as the ontology of letter-symbols, very successfully reveals the modern problems of personal identity.

In particular, this theory quite fundamentally reveals not only the psycholinguistic patterns of thought dependence on a particular language. So, this theory reveals letters-symbols, hieroglyphs, symbols as carriers of the essence of being, its foundations and its structure. Moreover, the open three universal basic generative systems of alphabetical plans form not only a different psycho-type for their carriers, but also lay down various prerequisites for the formation of the structures of the material substrate of the personality.

For example, the tendency to transform a person into asexual or disexual creation, which is gaining momentum in the countries that are carriers of one- and two-dimensional alphabetic plans, more than eloquently speaks of the psychophysical power of the archetypical minds, the symbols of which are the letters or hieroglyphs of a particular language. However, there is another degradation trend, which manifests itself in the framework of the generative structures of one-, two-dimensional alphabetic plans of the languages of the world. So one of the phenomenological features of these 
systems is the possibility of dividing the conditional straight line, along which the characters of letters or hieroglyphs into two symmetric segments are located.

In a similar way, already on the ontological horizon, the advantage of a number over a letter, spirit over a soul, logical calculation over conscience is achieved. The degradation tendency in these conditions is the appearance of a "body without organs" and/or a zombie body, a body detached from the higher limits of consciousness, but with elements of consciousness reflections. Otherwise, if do not use the transcendental variants of the zombie phenomenon, it is possible to clarify it, as the almost complete loss by the individual of his identity with the image of a rational person.

Today there are many theories of interpretation of the zombie phenomenon, theories about the origin of the term $[1,2]$. At the same time, one of the trends in the interpretation of this phenomenon was fixed by the film adaptation of the films "Night of the Living Dead" and "Dawn of the Dead" by J. Romero, in which "zombies" is the revived flesh of a dead person.

Most definitions also agree on the definition of this phenomenon, as a "mystical creature" and "living corpse" [2].

At the same time, the phenomenon and the "social zombie" is notorious in social psychology. In philosophical theoretical developments it is possible to find the concept of "philosophical zombies", as the term-appeal to the theories of physicalism and behaviorism. This term is also viewed as a thought experiment of the admissibility of being of an extremely rigid consciousness to reflection and active influence on the surrounding and inner world of its carrier. Moreover, in the philosophy of consciousness the argument of "philosophical zombies" is mentioned more often when considering theories that deny the reduction of consciousness to the physiology of brain activity $[3,4]$.

At the same time, the authors who adhere to these methodological guidelines do not take into account the newest theory of consciousness, the basis of which serves the judgment that the characters of three limiting groups of all languages of the world can form three psychological foundations of consciousness that are different in their transcendent and transcendental limits. That is, this theory (the theory of the alphabetical plans of world languages [5]) also adheres to the position of the irreducibility of consciousness to the physiology of brain activity, while also revealing the possibility to influence the psychological archetypes of consciousness (primal forms) on the physiology of the cerebral cortex and soft tissue of the brain. However, the subject of research is the clarification of the conditions and prerequisites for the formation of social matter of the phenomenon of zombie consciousness.

\section{The aim of research}

To reveal the correlation of one-, two-dimensional models of personal identity and ontology of a dead body without signs of consciousness ("zombies").

\section{Materials and methods of research}

The research materials are semantic concepts denoting the concept of "body" in most 19 European languages, as well as in hieroglyphic languages.

Based on the characteristics of the research materials, the author selects the appropriate research methods: hermeneutic and systemic structural. The author pays special attention to the phenomena of "philosophical, social, soulless zombies".

\section{Research results}

By zombie consciousness, let's first understand the possibility of an individual's consciousness to do only the mechanics of the consciousness of reflexes, as well as the consciousness of the intellect, the mind, built up in the personality into the absolute of all forms of thinking. This volume of the limits of consciousness is proposed to take into account as the lower limit of consciousness. This classification of the totality of reflexes, intellect and mind consciousness takes into account the development of D. Rosenthal about higher (HCL) and lower consciousness limits (LCL) [6]. D. Rosenthal understood the HCL as an opportunity to operate with mental states of the lower limits of consciousness (which include sensations, perceptions received from external objects of 
consciousness), and LCL incapable of such actions. The novelty of the author's interpretation of the higher limits of consciousness lies in enriching it with the approaches of the alphabetical plan theory of the languages of the world (A. Sviridov) [5]. Thus, the analysis of all 19 European languages, as well as all the hieroglyphic languages of the world, shows that linguistic consciousness based on their linguistic matter of speech is not able to comprehend the congruent forms of mind and soul consciousness.

Thus, the impossibility of analyzing by consciousness the congruent being of the mind, soul, within all the languages of the world based on the Latin alphabet and all hieroglyphic languages, characterizes its state as one of the LCL types. Consequently, in accordance with the previously adopted logic of research, this is a characteristic of one of the subspecies of the zombie phenomenon, zombie consciousness.

At the same time, the question of the impossibility of determining the consciousness of the intellect and mind to the arguments of a possible social zombie is rightly arising, since they allow the personalities to form their particular beliefs and judgments. However, as D. J. Chalmers notes, these judgments may not have a qualifying background (the notions of "qualia" are considered properties of sensory experience), but only contain the casual predicate of zombies control (from situation to situation, often by chance - author's comment - N. O.) [7, p. 88-110].

Also, within the semiosphere of all 19 European languages, let's find the phenomenology of "soulless zombie", one of the modifications/replications of the "philosophical zombie".

The sign of the lack of ontology of the structure of the soul in all 19 European languages, all hieroglyphic languages was thoroughly proved in the works of A. Sviridov. Let's briefly add that such concepts as: anima (Latin), Fren (Greek), 灵魂 (Chinese), 精神 (Chinese), Atman (आत्मन (Sanskrit), Buddhi (Sanskrit), (رُوحُ (ruh) (Arabic), הנשמה (Hebrew); רוח (Hebrew) (with the nesting/ root set of hieroglyphs: רוח), $\psi \ddot{u} \chi>\dot{~(G r e e k) ~-~ s p i r i t ~ a n d / o r ~ s o u l, ~ s p i r i t ~(E n g l i s h), ~ e s p r i t ~(F r e n c h), ~}$ gemüt (German), geist (German) directly indicate its (soul) semantic replacement by the concept of absolute spirit.

One of the effects of the semiosphere of the two-dimensional alphabetical plan of 19 European languages on the subconscious, the consciousness of Europeans in addition to the phenomenon of "soulless zombie" is the development of "neurological zombie" and "behavioral zombie" [8, p. 13] and "soulless zombie" [9, p. 55-70; 10, p. 355-374].

Such concepts, being formed on the basis of the "scattering" meanings of the concept of "soul", are amplified within the framework of perception by the individual and their body through the concepts of körper (German), body (English) - body and/or corpse, corpus (Latin) - a living body and, at the same time, a corpse, Le corps (French), chair (French) - meat and body at the same time. As a result, it forms a cognitive, neuroactive discord of the carriers of these concepts.

In hieroglyphic languages, this trend is preserved, for example, in Hebrew: גופה - body, dead body, corpse. These concepts directly affect the consolidation of this non-aesthetic and semi-mystical dualism of the perception of one's body by residents of European and Asian countries.

However:

1) the occult mystic of reviving the dead body within the framework of West African religious voodoo cults;

2) medical technology of poisoning of the cells of the cerebral cortex;

3) short-term excretion of the human psyche to the borderline states of consciousness for the emergence of "nzambi (zombie)" - the spirit of the deceased person "can't be compared with the scale of actions on the personality of the concepts of "behavioral zombies", "neurological zombies" and "soulless zombies" in the framework of semantic viruses, forming the linguistic consciousness of the individual.

Turning to the super-unified theory of the physical and semantic field - the theory of alphabetical plans, let's note that the well-promoted image of zombies by Western cinema, despite its ugliness, is an attempt by Western society to understand itself through the objects of "ugly aesthetics".

Otherwise, it is essentially a reproduction of the concept, which, having a marked dualistic nature, forms the neurotic symptoms of a personality, which is forced to repeatedly experience the 
unconscious complex of bifurcation of personal identity on the body of a living person and the body of a dead person.

Within our methodology, let's unconditionally accept the fact of the active participation of the semantic field of a language in the development of a one-, two- or three-dimensional model for structuring personal identity. In that, the number of structuring and transcendental forms (soul, spirit) and material (body) forms of personality.

Regarding the concept of one-, two-dimensional model of personal identity, it is necessary to clarify that by this concept we understand the limited ability of an individual to perceive the integrity of both the spiritual and physiological substratum of the personality. Earlier, such a truncated unity (truine, but not the trinity) was revealed through the "tetraxis" concept. The peculiarity of this quasi-three-dimensional figure (in relation to the three-dimensional structure of the "tetrad") is the presence of the heaped structure of the psychological substrate of the personality. Such structures as a spirit and a soul turn out to be fused; intelligence and reason; mind and spirit into a single indistinguishable ontic and phenomenological conglomerate. Such conglomerates are most typical for European languages and all hieroglyphic languages. The ontological identity of the basic categories of the personality, the basic categories of the consciousness of the personality leads to the impossibility to build up a full-fledged personal identity in the framework of the transcendental and material form of its being.

Within these semiospheres, the nondiscrimination of minds from minds, intellect, mind actually indicates the absence of minds that congruent to their name, as an organizing form of consciousness and soul consciousness (an integrating form of consciousness), which is one of the main signs of being physiological (behavioral) and psychological, social, philosophical zombies.

In essence, such concepts as: anima (lat.), Fren (Greek), 灵魂 (Chinese), (精神 (Chinese), Atman (आत̄मन (Sanskrit), Buddhi (बुद्धि (Sanskrit), הנשמה (Hebrew); רוח (He-

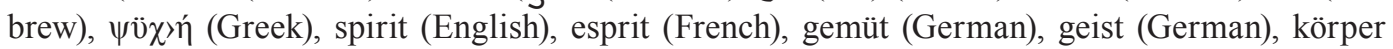
(German), body (English), corpus (Latin), Le corps (French), chair (French) are the bases for maintaining signs of "zombies" in their speakers - linguistic personalities oriented to one -, two-dimensional models of being and one-dimensional, two-dimensional models of personal identity.

One example of the effect of "behavioral zombies", which, within the framework of the behavioral reactions of their consciousness, is not capable of distinguishing the fact of replacing the aesthetics of the beautiful with the aesthetics of the ugly, is replacing the ontology of the angel Lucifer with the ontology of Satan, the devil.

It is noteworthy that Lucifer was originally understood as the god of the morning star (Lucifer, feri m 1) Lucifer, the son of Aurora, the god of the morning star O; 2) the morning star (planet Venus)) [11, p. 601], an analogue of the ancient Russian god Dennitsa. However, in the writings of Jerome of Stridon, it becomes an analogue of Satan.

Even in the New Testament, Jesus tries to compare himself with Lucifer, Dennitsa, in a figurative sense, with the "morning star" (Rev. 22:16; 2 Pet. 1:19). However, attempts to distort the primary meaning of the phenomenon of the "morning star" - Lucifer in the framework of the works of Jerome of Stridon achieved their "success". One consequence of the theoretical corrections of the meanings of the concept "Lucifer" by Jerome for the philosophy of Christianity was the opportunity to equalize the comparative transposition of Joshua himself to the concept "morning star" and Satan. It is noteworthy that there are no ontologies of diverging meanings in the Latin concept of "Lucifer" (Latin), no [11, p. 601]. However, within the culture of two-dimensional religious philosophy of Christianity, still developing within the two-dimensional dimension of the semiosphere of the Latin alphabet, there is a peculiarity of accepting the concepts of "childbirth", "maternity", "birth" in the semantic shell of the word "rode" (Latin) - devour, consume. Which means that the process of generating new knowledge, filling it with the structure of personal identity with new meanings (meaning the comparison of Lucifer and the astrological symbol of Aquarius in the frame of G. H. Frezza, 1704 engraving) in the semantics of the notion "rode" (Latin) is actually perceived at the subconscious level as a dead end of the "development" of a linguistic personality limited to the in-itself.

At the same time, the "eye of Lucifer", inscribed in the primary body of "fire", sacredly revered by the "moral-ethical" movement of the Freemasons, in their tradition turned into a two-di- 
mensional projection of the fisheye lens. Such symbolism in their performance no longer carries a sign of the luminosity of Lucifer's consciousness, but on the contrary carries a sign of fading elliptical galaxies, the process of star formation in which is stopped. At the same time, the god of dawn, which they adore, does not in vain receive a habitual existence only in the form of the eye, the all-seeing eye, since similarly the keyhole of the all-seeing eye hides the very non-aesthetic archetypical image of the bountiful cosmic man Adam Kadmon. We have already clarified earlier that the Old Testament man A. Kadmon is one of the clearest examples of the one-dimensional model of personal being, "one-dimensional man" (including as understood by G. Markuse).

This definition clearly enough unites the ontology of the "eye of Ra", "Wadget", "all-seeing eye" of masons, since the symbol "eye of Ra", as the primary source of this series of symbols, is the female self of the god of the Sun in ancient Egyptian society. The eye in religion often correlates with the phenomenology of the light of truth. In this case, the male image of Lucifer is attracted through the image of the rays from the "all-seeing eye". That is, in the symbol of the Masons mixed up to non-discrimination, both female and male hypostasis. By the totality of the analysis of the symbol, it is a sign of the presence of disexual A. Kadmon, the congruent dual nature of the demon (which is neither soul nor spirit definitely) - "the great architect of the Universe", Logos.

Thus, the semiosphere of the Latin through the two-dimensional alphabetic plans of all 19 European languages today carries an archetypal image of aversion to spiritual development. At the same time, the so-called "spiritual development" in the framework of the semiosphere of the alphabetic plans of two-dimensional dimension of 19 European languages today actually has signs of para-spiritual and anti-spiritual development. The example of the substitution of the "god of the morning dawn" (Lucifer) for the "devil" (Satan) within the framework of the Latin language quite clearly shows that we are dealing with a large-scale formula, a matrix that distorts and exalts the sublime senses of the soul, conscience, and creativity of new meanings from the identity of their carriers (linguistic personalities). Similar examples are also clear evidence of the linguistic transformation of the consciousness of Europeans over the past 2,000 years. They also testify about the substitution of higher order consciousness on lower consciousness, combining the senses of being of a living body and a corpse (dead body), which is actually one of the signs of the formation of the realities of the society of "behavioral zombies", "neurological zombies", and "soulless zombies". The criticism of some authors about the fundamental impossibility of such social realities [12], in general, contains only an intensification of the argument in favor of this fact.

At the same time, the author emphasizes that it is the one- and two-dimensional language plans that contain similar "favorable" conditions for psycho-linguistic manipulations with their native speakers (linguistic personalities). The author admits that probably not all carriers of concepts containing the dynamics of "scattering" of the meanings of the basic categories of personal identity (soul, spirit, body) will be the direct spokesmen of the zombie aesthetics. However, the threat that language personalities do not realize today, the carriers of these concepts, is quite real and is directed against a set of linguistic individuals who do not use the semi-sphere of the three-dimensional alphabetical plan to realize their sustainable existence. Thus, among Western experts in the field of the philosophy of consciousness, they completely do not deny combining the concept of social zombies and all people of the planet Earth $[8,9]$. Of course, the conclusion is made through the syllogism of denying the promise of the possibility of consciousness in principle. However, this fact does not remove the fact that we discovered about the predisposition of a linguistic person, comprehending its being within the framework of the archetypes of the Latin, the transition to the "rationing" of being social, soulless zombies. The letters of the Latin in this case are considered as primary forms of the limited consciousness of the individual beyond the consciousness of the intellect and mind.

We have defined this limitation of the limits of consciousness as the lower limits of consciousness accumulating, in turn, antinomical judgments of the "social, neurological, soulless zombie" type by means of the limited linguistic matter of all 19 European languages and all hieroglyphic languages of the world. As part of our methodology, the totality of these languages is a condition for the formation of models of personal identity that are limited in their structural composition - one-, two-dimensional. The essence of these models of personal identity, including, is their 
inability to fully disclose the transcendent and transcendental forms of being of the individual. In this case it means the impossibility of qualitatively revealing the being of the soul and the being of the spirit as essentially different entities. In turn, the impossibility of most fully revealing the transcendental form of personal identity (soul, spirit) is mediated by the absence of tools in the form of concepts of linguistic matter of speech. Within the framework of the ontological conditions of existence of one-, two-dimensional models of personal identity, there are semantic concept transformers of its structure of the form: anima, fren, 灵魂, आत्मन, body, corpus, etc.

In the Russian language, there are no similar concepts-transformers of personalities in carriers of the aesthetics of the ugly - there is no aesthetics of "zombies" (see the concept of the body in the explanatory dictionaries of the Russian language) [14, p.1979]. In the Russian language, on the contrary, there are foundations of linguistic matter of speech for understanding oneself as a person within the framework of a three-dimensional model of personal identity. In which (three-dimensional model of personal identity) there are reasons to form a three-dimensional I-concept, within which soul and spirit are not generalized into a single ontic conglomerate, and the body does not receive a dichotomous image: a corpse and a living body [15, p. 118-122; 16, p. 37-41].

\section{Conclusions}

1. The relevance of studying the conditions for the formation of two-dimensional models of personal identity is substantiated, which are characterized by the regressive tendency to unite the dead and living body at the ontological and phenomenological levels of events.

2. Approaches to the generalization of the phenomenon of "social zombies", "behavioral zombies" and "soulless zombies" are identified. In the context of these generalizations, their methodological deadlock is revealed, which do not allow to identify the conditions for their formation. In this context, it is proposed to use the theory of the alphabetical plans of the world languages of A. Sviridov to clarify that it is the linguistic matter of alphabetic plans of one-, two-dimensional dimension (all 19 European languages and all hieroglyphic languages) is the leading factor in the formation of the "social zombie" onticity.

3. On the example of the equalization on the ethical, moral and rhetorical levels of completely polar phenomena (Satan and the god of dawn-light, Lucifer), the tendentiousness of the realities of modern society in terms of the formation of the zombie phenomenon through concepts such as: körper (German), body (English), corpus (Latin), Le corps (French), chair (French).

Thus, it is concluded that the self-consciousness of the individual, which expresses its self-identity within the framework of the dichotomous concepts of the living body and the corpse, becomes the real carrier of personal identity, including intimatism and the phenomenology of zombies.

4. In Russian language thinking there are no linguistic rhetorical concepts capable of forming in society the primacy of one-, two-dimensional models of personal identity.

\section{References}

[1] Alekseev, A. Yu. (2009). Ponyatie «zombi» i problema soznaniya. Problema soznaniya v filosofii i nauke. Moscow: Kanon +, 195-214.

[2] Krysina, L. P. (2006). Zombi Tolkovyy slovar' inostrannykh slov. Moscow: Eksmo, 285.

[3] Garntseva, N. M. (2009). Antifizikalistskie argumenty v uchenii D. Chalmersa o soznanii. Voprosy filosofii, 5, 93-105.

[4] Chalmers, D. (2010). The two-dimensional argument against materialism. The character of consciousness, 141-206. doi: http://doi.org/10.1093/acprof:oso/9780195311105.003.0006

[5] Sviridov, A. A. (2012). Russkiy fundamentalizm. Azbuka masshtabnykh peremen. Vol. 11: Rodoslovie k cheloveku $\equiv$ Kniga ROD”A. Arkaim, 436.

[6] Lau, H., Rosenthal, D. (2011). Empirical support for higher-order theories of conscious awareness. Trends in Cognitive Sciences, 15 (8), 365-373. doi: http://doi.org/10.1016/j.tics.2011.05.009

[7] Beaton, M. (2009). Qualia and introspection. Journal of Consciousness Studies, 116 (5), 88-110.

[8] Hughes, D. P., Andersen, S. B., Hywel-Jones, N. L., Himaman, W., Billen, J., Boomsma, J. J. (2011). Behavioral mechanisms and morphological symptoms of zombie ants dying from fungal infection. BMC Ecology, 11 (1), 13. doi: http://doi.org/10.1186/1472-6785-11-13 
[9] Lashua, B. D. (2015). Zombie Places? Pop Up Leisure and Re-Animated Urban Landscapes. Landscapes of Leisure. London Palgrave Macmillan, 55-70. doi: http://doi.org/10.1057/9781137428530_5

[10] Graef, O. de. (2014). "I Know He Knows I Know He Knows I Am”: Suspension of Disbelief in A. L. Kennedy. Partial Answers: Journal of Literature and the History of Ideas, 12 (2), 355-374. doi: http:// doi.org/10.1353/pan.2014.0026

[11] Dvoretskiy, I. Kh. (1976). Latinsko-russkiy slovar'. Okolo 50000 slov. Moscow: Russkiy yazyk, 601.

[12] Volkov, D. B. (2012). Boston Zombie: D. Dennett and His Theory of Consciousness. Moscow: Librocom, 320.

[13] Shilova, G. E., Sternin, I. A. (2005). Chastotnyy slovar' inoyazychnykh slov (po materialam publitsistiki). Voronezh: Izdatel'stvo «Istoki», 127.

[14] Ozhegov, S. I. (2011). Tolkovyi slovar' russkogo yazyka. Moscow: Mir i Obrazovanie, Oniks, 736.

[15] Nikolov, N. O. (2018). Sravnenie odnomernoy: «ya=ego (telo i anima)» i trekhmernoy modeli lichnostnogo bytiya: «ya=russkaya troyka (dusha, dukh i telo)» v «perimetrakh bukv» 19 evroyazykov i russkom yazyke. KANT, 3, 118-122.

[16] Nikolov, N. O. (2012). Kategoriya tela cheloveka v triedinstve modeli «Ya - russkoy troyki»kak dushi, tela i dukha v rezhime «laboratoriy» mysli programmy «razumogeneza», programmy «intellektgeneza». Global'nyy nauchnyi potentsial, 7 (16), 37-41. 